\title{
Summary of recommendations for the prevention of malaria by the Committee to Advise on Tropical Medicine and Travel (CATMAT)
}

\author{
Boggild $A^{1}$, Brophy $\mathrm{J}^{2}$, Charlebois $\mathrm{P}^{3}$, Crockett $\mathbf{M}^{4}$, Geduld $\mathrm{J}^{5}$, Ghesquiere $\mathbf{W}^{6}$, McDonald $\mathrm{P}^{7}$, \\ Plourde $\mathrm{P}^{8}$, Teitelbaum $\mathrm{P}^{9}$, Tepper $\mathrm{M}^{10}$, Schofield $\mathrm{S}^{11}$ and McCarthy $\mathrm{A}$ (Chair) ${ }^{12^{\star}}$ \\ 1 University Health Network, Toronto General Hospital (Toronto, ON) \\ 2 Division of Infectious Diseases, Children's Hospital of Eastern Ontario (Ottawa, ON) \\ 3 Internal Medicine, Canadian Forces Health Services Centre (Atlantic) (Halifax, NS) \\ 4 Paediatrics and Child Health, University of Manitoba (Winnipeg, MB) \\ 5 Infectious Disease Prevention and Control Branch, Public Health Agency of Canada (Ottawa, ON) \\ 6 Infectious Diseases and Internal Medicine, University of British Columbia (Victoria, BC) \\ 7 Therapeutic Products Directorate, Health Canada (Ottawa, ON) \\ 8 Faculty of Medicine, University of Manitoba (Winnipeg, MB) \\ 9 Riverside Travel Medicine Clinic (Ottawa, ON) \\ ${ }^{10}$ Communicable Disease Control Program, Directorate of Forces Health Protection (Ottawa, ON) \\ ${ }^{11}$ Pest Management Entomology, Directorate of Forces Health Protection (Ottawa, ON) \\ 12 Tropical Medicine and International Health Clinic, Division of Infectious Disease, Ottawa Hospital General Campus \\ (Ottawa, ON) \\ * Corresponding author: AMcCARTHY@Ottawahospital.on.ca
}

\section{Abstract}

Background: On behalf of the Public Health Agency of Canada, the Committee to Advise on Tropical Medicine and Travel (CATMAT) developed the Canadian Recommendations for the Prevention and Treatment of Malaria Among International Travellers for Canadian health care providers who are preparing patients for travel to malaria-endemic areas and treating travellers who have returned ill.

Objective: To provide guidelines on risk assessment and prevention of malaria

Methods: CATMAT reviewed all major sources of information on malaria prevention, as well as recent research and national and international epidemiological data, to tailor guidelines to the Canadian context. The evidencebased medicine recommendations were developed with associated rating scales for the strength and quality of the evidence.

Recommendations: Used together and correctly, personal protective measures (PPM) and chemoprophylaxis very effectively protect against malaria infection. PPM include protecting accommodation areas from mosquitoes, wearing appropriate clothing, using bed nets pre-treated with insecticide and applying topical insect repellant (containing $20 \%-30 \%$ DEET or $20 \%$ icaridin) to exposed skin. Selecting the most appropriate chemoprophylaxis involves assessment of the traveller's itinerary to establish his/her malaria risk profile as well as potential drug resistance issues. Antimalarials available on prescription in Canada include chloroquine (or hydroxychloroquine), atovaquone-proguanil, doxycycline, mefloquine and primaquine.

\section{Introduction}

Malaria is a serious infection caused by five different species of the genus Plasmodium: falciparum, vivax, ovale, malariae and knowlesi. Malaria is transmitted by the bite of infected female anopheline mosquitoes.

In $2009,35 \%$ of Canadian travellers who went to a destination other than the United States visited a country that presented a risk of malaria, an increase of 131\% from 2000 (1-2). Between September 2009 and September 2011, 94 cases of malaria were diagnosed among returned Canadian travellers (3). 
According to the Centers for Disease Control and Prevention (CDC), malaria risk for travellers from the United States (4-6) varied as follows:

- Highest in west Africa and parts of Oceania;

- Moderate for other parts of Africa, parts of South America and South Asia;

- Lower for much of Central America, the Caribbean, Mexico and other parts of Asia and South America;

- Minimal in urban centres of southeast Asia and Central and South America, and in large resort areas in the Caribbean and Mexico.

The Committee to Advise on Tropical Medicine and Travel (CATMAT) provides the Public Health Agency of Canada with ongoing and timely medical, scientific and public health advice relating to tropical disease and health risks associated with international travel. This is a summary of the CATMAT Canadian Recommendations for the Prevention and Treatment of Malaria Among International Travellers, developed for Canadian health care providers who are preparing patients for travel to malaria-endemic areas and treating travellers who have returned ill (7). These guidelines include a full description of the recommendations on risk assessment and prevention of malaria, a disease that is still uncommon in Canada.

\section{Methods}

The Malaria Subcommittee, a working group of CATMAT, developed the guidelines. Each member is a volunteer, and none declared a relevant conflict of interest. Each chapter was updated by one to two members of the subcommittee and reviewed and approved by the full membership of CATMAT. The update was based on a thorough review of the literature. In addition, the Malaria Subcommittee reviewed all major sources of information on malaria prevention and treatment, including the World Health Organization (8), Centers for Disease Control and Prevention (CDC) (6) and the Health Protection Agency Advisory Committee on Malaria Prevention (9). The Malaria Subcommittee reviewed recent research, and national and international epidemiological data in order to tailor the recommendations to the Canadian context. Influencing factors include drug licensure, Canadian-specific travel patterns and related malaria epidemiology, and the anticipated values and preferences of travellers and health care providers. The evidence-based medicine recommendations for prevention of malaria were developed with associated rating scales for the strength and quality of the evidence.

CATMAT has taken into consideration both the need for protection and the potential for adverse effects of chemoprophylaxis. The guidelines also emphasize the varying degrees of endemicity in different regions. The health care provider should be properly informed to be able to provide appropriate guidance for the individual traveller. 


\section{Recommendations}

The evidence-based CATMAT recommendations for malaria prevention are summarized in Table 1. A discussion of some of the key recommendations follows.

\section{Table 1: Evidence-based medicine recommendations for prevention of malaria}

\section{Recommendation}

1. Properly used malaria chemoprophylaxis is very effective (6).

EBM rating ${ }^{1}$

2. Travellers should receive expert advice on malaria risks and strategies to avoid mosquitoes (10).

3. A detailed review of the travel itinerary to determine the expected level of malaria endemicity and duration of exposure is essential to provide an accurate risk assessment for travellers $(6,10,11)$.

4. An assessment of the traveller's health and risk tolerances is also important in making malaria prevention recommendations.

5. It is very important to adhere to recommended malaria prevention practices (e.g. use of chemoprophylaxis and PPM) (12-22).

6. Chloroquine $\left(\right.$ Aralen $^{\circledR}$ ) or hydroxychloroquine (Plaquenil ${ }^{\circledR}$ ) is the drug of choice for travellers to areas with chloroquine-sensitive malaria (23).

7. Atovaquone-proguanil, doxycycline or mefloquine is the drug of choice for travellers to areas with chloroquine-resistant or mefloquine-sensitive malaria (12-14,24-27).

8. Atovaquone-proguanil and doxycycline are the drugs of choice for travellers to areas with mefloquine-resistant malaria.

9. Primaquine is recommended for malaria chemoprophylaxis for travellers to regions with chloroquine resistance who are not willing or able to use atovaquone-proguanil, doxycycline or mefloquine.

10. Standby malaria treatment with atovaquone-proguanil or quinine and doxycycline is recommended for travellers who are more than a day away from malaria diagnostic help.

11. Doxycycline is an antibiotic and should never be co-administered with any live, oral bacterial vaccines. Vaccination with live oral typhoid or cholera vaccines should be completed at least three days before the first dose of choloroquine, atovaquone-proguanil or mefloquine.

12. Concurrent use of chloroquine interferes with antibody response to intradermal administration of human diploid cell rabies vaccine. If intradermal rabies vaccine is administered to someone taking chloroquine, it is recommended that post-vaccine rabies antibodies be obtained to verify an adequate immunologic response.

13. Use insecticide-treated bed nets.

\section{A I}

14. Use topical repellents on exposed areas of skin to prevent arthropod bites and to reduce the risk of exposure to malaria-carrying mosquitoes.
B III

B III

B III

B III

A I

A I

A I

A I

C III

B III

B III

15. Products registered in Canada that contain 20\%-30\% DEET (N,N-Diethyl-meta-toluamide) or $20 \%$ icaridin should be the first choice for Canadian travellers.

16. Products that contain $p$-menthane-3,8-diol (a chemical originally derived from the lemon eucalyptus plant) and that are registered in Canada should be considered second-choice topical repellents.

17. Other active ingredients currently registered in Canada (e.g. citronella and soybean oil) are either not widely available and/or do not provide sufficiently long protection times against bites. These products are not recommended for protecting travellers against the bites of vectors.

18. Protect work and accommodation areas against mosquitoes by using screening on doors, windows and eaves (the open area between the roof and wall), eliminating holes in roofs and walls, and closing other gaps around a building. 


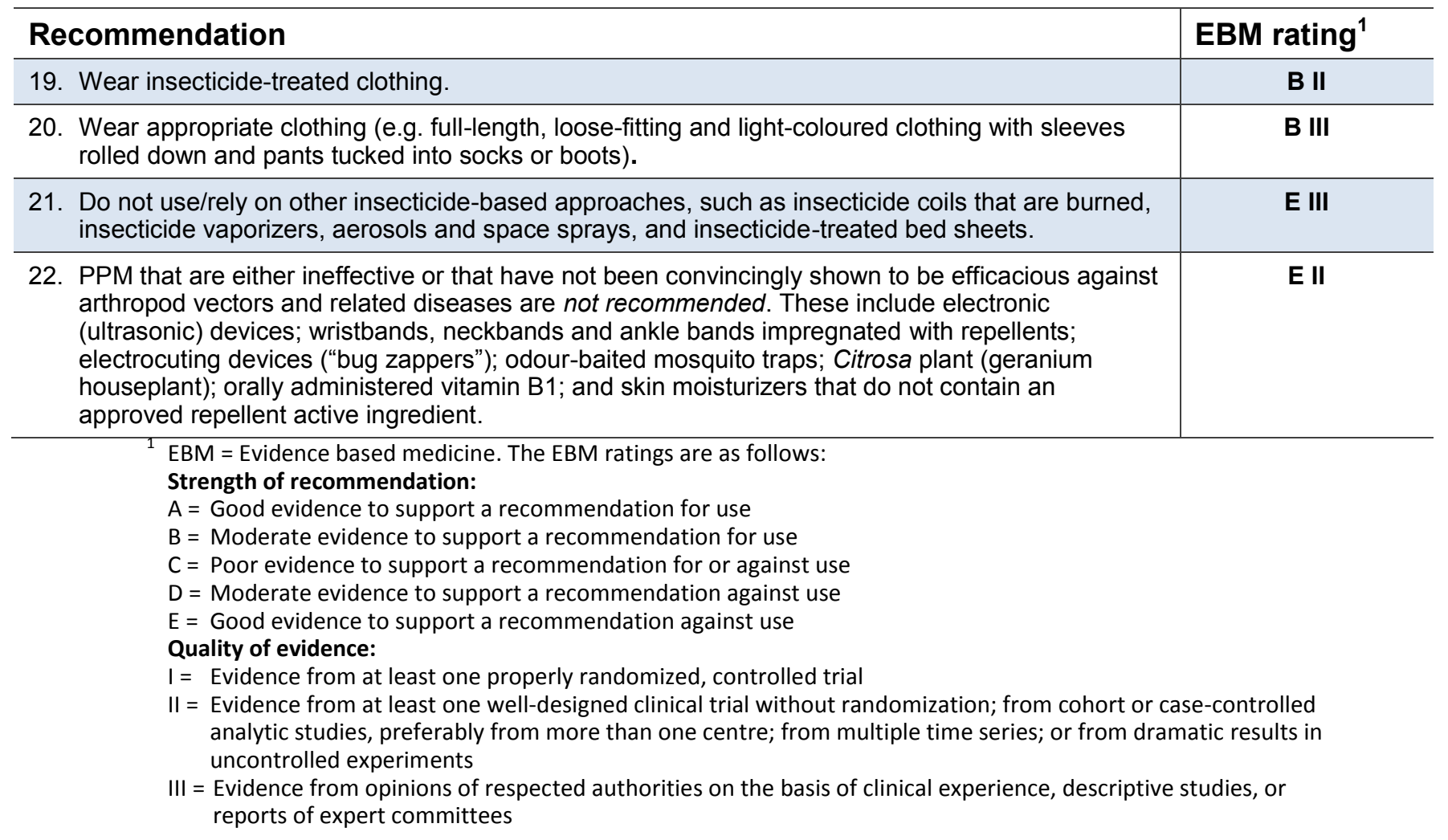

\section{Risk assessment}

CATMAT suggests a two-component process for malaria risk assessment: an exposure assessment and a host assessment.

An exposure assessment evaluates the probability of being bitten by infected mosquitoes. It takes three factors into account:

- $\quad$ Expected level(s) of endemicity in the travel itinerary;

- $\quad$ Presence/predominance of P. falciparum;

- Duration of exposure.

A host assessment evaluates the traveller's health in relation to the potential hazard(s) of clinical malaria and the indications for specific malaria chemoprophylactic agents while taking into account personal preferences regarding risk management. Factors to consider include the following:

- General health of the traveller;

- Drug-drug interactions;

- Likelihood of access to appropriate medical care;

- $\quad$ Risk tolerance and individual preferences.

The completed risk assessment can be used to decide whether to use malaria chemoprophylaxis and which chemoprophylactic agent to prescribe:

- If malaria risk is minimal and the incidence of $P$. falciparum is nil or very low, CATMAT recommends using chemoprophylaxis (with PPM) for a stay longer than two weeks.

- If malaria risk is minimal and the incidence of $P$. falciparum is higher, CATMAT recommends chemoprophylaxis (with PPM) for a stay longer than one week. 
Travellers who decide not to use chemoprophylaxis have a higher risk of malaria but lower risk of chemoprophylaxis-associated adverse effects; the opposite is true for those who decide to use it.

A country-by-country characterization of malaria transmission areas is available in the complete guidelines (7). The Appendix provides chemoprophylaxis recommendations for the top 25 destinations with risk of malaria transmission that are visited by Canadians.

\section{Personal protective measures}

- The risk of being bitten by a mosquito can be reduced by using physical and/or chemical barriers.

- Physical barriers:

- Screening on doors, windows, eaves and other gaps in the building (28-30);

- Bed nets treated with insecticide (31-33);

- Full-length, loose-fitting and light-coloured clothing (clothes can also be treated with insecticide).

- Chemical barriers repel mosquitoes and/or kill them $(34,35)$. The main chemical modalities currently available are topical insect repellents for use on exposed skin and insecticides that impregnate bed nets and clothing (36-40).

- Topical repellents should contain $20 \%-30 \%$ DEET or $20 \%$ icaridin.

- Alternatively, second-choice topical repellents are those containing $p$-menthane-3,8-diol that are registered in Canada.

Travellers should also be encouraged to plan activities during periods when risk is reduced (e.g. during the daytime where the principal vectors are active in the evening) and to visit areas where transmission is less likely (e.g. urban centres, highland areas $>2000 \mathrm{~m} / 6500 \mathrm{ft}$ ).

\section{Chemoprophylaxis}

\section{Prescribing antimalarial drugs}

Prescribe antimalarial chemoprophylaxis only after completing an individual risk assessment. For detailed descriptions of chemoprophylaxis and of chemotherapy see Chapter 8 of the Canadian Recommendations for the Prevention and Treatment of Malaria Among International Travellers (7). Selecting the most appropriate chemoprophylactic agent involves the following:

1. Evaluate the traveller's exact travel itinerary to determine his or her malaria risk profile.

2. Review the advantages and disadvantages of different regimens:

- Take into account the traveller's health status, other medications and the risks and character of adverse drug effects.

- Consider only those medications that are least likely to exacerbate any past or present medical problem(s).

3. Present all the available options to the traveller and, unless any medication is contraindicated, let travellers choose which first-line malaria chemoprophylactic regimens they prefer.

4. Select the appropriate dosage of the medication:

- Explain the dosing schedule, including the need to take the drug before, during and after visiting the area of risk, the desirability of taking the drug at the same time each day and advice on whether the prescribed medication should be taken with food, as well as any precautions regarding drug-specific side effects (e.g. sun exposure with doxycycline) (41-47).

5. Suggest a drug trial to check for possible medication-associated adverse reactions.

6. Discuss strategies to change medication if serious adverse effects arise during travel.

- Advise the traveller to continue to take the prescribed malaria medication if it is well tolerated regardless of negative anecdotes about it. Long-term use of the chemoprophylactic agents currently recommended in Canada does not result in additional risks of severe adverse effects. 
Discuss the importance of seeking medical advice urgently if a fever develops while the traveller is in a malariaendemic area or within one year of leaving.

\section{Selecting antimalarial drugs for specific regions of drug resistance}

Monitor appropriate sources (e.g. Public Health Agency of Canada, CDC, ProMED) to stay abreast of new information about malaria risks before giving pre-travel care. This is especially relevant for minimal-risk regions because changes may directly affect the recommendations for chemoprophylaxis.

Table 2: Selecting antimalarial drugs for specific regions of drug resistance

\begin{tabular}{|c|c|}
\hline Area/region $(6,48-50)$ & Drugs of choice \\
\hline $\begin{array}{l}\text { Chloroquine-sensitive regions: } \\
\text { Haiti, the Dominican Republic, Central America north of } \\
\text { the Panama Canal, parts of Mexico, parts of South } \\
\text { America, north Africa, parts of the Middle East, and } \\
\text { west/central China }\end{array}$ & $\begin{array}{l}\text { Chloroquine }\left(\operatorname{Aralen}^{\circledR}\right) \\
\text { Hydroxychloroquine }\left(\text { Plaquenil }^{\circledR}\right) \text { is an acceptable } \\
\text { equivalent alternative }(51) \text {, as are the three drugs used in } \\
\text { chloroquine-resistant areas (see below). }\end{array}$ \\
\hline $\begin{array}{l}\text { Chloroquine-resistant regions: } \\
\text { Most of sub-Saharan Africa, South America, Oceania } \\
\text { and Asia. See below for regions that are both } \\
\text { chloroquine- and mefloquine-resistant. }\end{array}$ & $\begin{array}{l}\text { Atovaquone-proguanil }(41,42,44-47,52) \\
\text { Doxycycline }(41,42,44-47,52) \\
\text { Mefloquine }(41,42,44-47,52)\end{array}$ \\
\hline $\begin{array}{l}\text { Chloroquine- and mefloquine-resistant regions: } \\
\text { Various countries in Asia, Africa and the Amazon basin. } \\
\text { However, it is a significant problem only in rural, wooded } \\
\text { regions where Thailand borders with Myanmar (Burma), } \\
\text { Cambodia and Laos, and in southern Vietnam. }\end{array}$ & $\begin{array}{l}\text { Atovaquone-proguanil }(44,53,54) \\
\text { Doxycycline }(44,53,54)\end{array}$ \\
\hline
\end{tabular}

Note: See the Appendix, 'Malaria risk and recommended chemoprophylaxis in top 25 malaria-endemic travel destinations visited by Canadians in 2012', or a more complete list in the Canadian Recommendations for the Prevention and Treatment of Malaria among International Travellers (7).

\section{Discontinuing antimalarial drugs}

Fatal malaria has occurred in travellers who have discontinued all chemoprophylaxis or effective chemoprophylaxis in favour of something less protective $(24,51,55,56)$. Discontinuation of all chemoprophylaxis is NOT a reasonable option.

Other travellers and/or health care providers may suggest changing or stopping antimalarial medication. For the most part, such advice should be ignored or questioned. Medications used in other areas of the world may be less effective, may be associated with serious adverse effects or may not be manufactured to Canadian standards. Examples include proguanil alone $\left(\right.$ Paludrine $^{\circledR}$ ), pyrimethamine (Daraprim ${ }^{\circledR}$ ), dapsone-pyrimethamine (Maloprim ${ }^{\circledR}$ ) and mefloquine-sulfadoxine-pyrimethamine (Fansimef $f^{\circledR}$ ).

However, if the traveller experiences significant adverse events because of the chemoprophylactic agent, the medication can be changed, especially if the advice is provided by a health care provider (preferably the one who provided the initial advice).

\section{Adherence to chemoprophylaxis}

The reasons for non-adherence include lack of knowledge that malaria was a threat; fear of or past experience with adverse effects of chemoprophylactic agents; the false belief that prior malaria infections have conferred long-term immunity; the cost of medications; and confusion arising from contradictory recommendations. However, there is little information on how to enhance adherence.

Non-adherence to or suboptimal use of chemoprophylaxis and other preventive interventions is common, particularly among backpacking travellers; immigrants returning to visit their country of origin; people travelling for 
longer than one month; travellers aged 40 years or less; and those using chemoprophylactic agents that must be taken daily $(12-21,23,25-27,57)$.

Health care providers themselves need to be properly informed to be able to provide appropriate guidance (58). Travellers who use one qualified information source, such as a family physician trained in travel medicine, are significantly more likely to be compliant with malaria prophylaxis than those who collect information from multiple sources that could contradict each other $(58,59)$.

\section{Summary}

A summary of the key changes made to the 2014 Guidelines are noted in Table 3.

Table 3: Summary of key additions and changes to the 2014 Guidelines pertaining to prevention of malaria (7)

\begin{tabular}{|c|c|}
\hline \multicolumn{2}{|c|}{ Additions } \\
\hline & $\begin{array}{l}\text { The addition of a length-of-stay threshold for use of malaria chemoprophylaxis so that health care providers can } \\
\text { better tailor individualized risk assessments (see Chapter 2). }\end{array}$ \\
\hline & $\begin{array}{l}\text { A new insect repellent, } 20 \% \text { icaridin, is recognized as an equivalent to DEET as a first-line choice for mosquito } \\
\text { repellent (see Chapter 3). }\end{array}$ \\
\hline & $\begin{array}{l}\text { The guidelines have been expanded for populations requiring special attention - children, migrants, expatriates } \\
\text { and travellers visiting friends and relatives, women who are pregnant or breastfeeding, and travellers with co- } \\
\text { morbidities (Chapter 5). }\end{array}$ \\
\hline & $\begin{array}{l}\text { A new "Malaria Card" that can be given to travellers with information about their malaria chemoprophylaxis and an } \\
\text { important reminder to seek medical attention in the event of a fever illness after travel. }\end{array}$ \\
\hline \multicolumn{2}{|c|}{ Changes } \\
\hline & $\begin{array}{l}\text { Chapter 4, "Prevention - Chemoprophylaxis Regimens," has been refined to make it easier to navigate the drug } \\
\text { choices available. These changes include a simplified, step-wise approach to selecting malaria prophylaxis; } \\
\text { comprehensive listings of medications and malaria risk by country/area in tabular form; and expanded explanation } \\
\text { of the differences in approaches to malaria prophylaxis in other jurisdictions. }\end{array}$ \\
\hline & $\begin{array}{l}\text { Chapter 8, "Drugs for the Prevention and Treatment of Malaria," includes an update on primaquine use for malaria } \\
\text { prophylaxis and prevention; additional up-to-date information on pediatric dosing of atovaquone/proguanil; and } \\
\text { general updates to Table 8.11: Drugs (generic and trade name) for the treatment and prevention of malaria. } \\
\text { Revisions have also been made to the following sub-sections related to malaria prevention: chloroquine and } \\
\text { mefloquine (with increased emphasis on selection or avoidance of this drug according to individual tolerability). }\end{array}$ \\
\hline
\end{tabular}

\section{Acknowledgements}

CATMAT acknowledges and appreciates the contribution of Joanna Odrowaz, Elspeth Payne to the development of the summaries and Manisha Kulkarni for her contribution to the statement.

CATMAT Members: Boggild A, Brophy J, Bui YG, Crockett M, Ghesquiere W, Greenaway C, Henteleff A, Libman $M$, Teitelbaum $P$ and McCarthy $A$ (Chair).

Liaison members: Hui C (Canadian Paediatric Society) and Gershman M (US Centers for Disease Control and Prevention).

Ex-officio members: Marion D (Canadian Forces Health Services Centre, Department of National Defence), McDonald P (Division of Anti-Infective Drugs, Health Canada), Schofield S (Directorate of Force Health Protection, Department of National Defence), and Tepper M (Directorate of Force Health Protection, Department of National Defence). 
Member Emeritus: Jeanes CWL.

\section{Conflict of interest}

There are no conflicts of interest to declare.

\section{Funding}

This work was supported by the Public Health Agency of Canada.

\section{References}

(1) World Health Organization. World Malaria Report 2012. 2012:1-195.

(2) Geduld J, Bryson M, Straight-Caron T. Canadian Trends of International Travel and Risk of Malaria Exposure, 12th Conference of the International Society of Travel Medicine, May 8-12, 2011, Boston, US. 2011.

(3) Boggild A, Geduld J, Libman M, Ward B, McCarthy A, Doyle P, Ghesquiere W, Vincelette J, Kuhn S, Freedman $D$, Kain K. Travel-acquired infections and illnesses in Canadians: surveillance report from CanTravNet surveillance data, 2009-2011. Open Med 2014;8(1).

(4) Mali S, Tan KR, Arguin PM. Division of Parasitic Diseases and Malaria, Center for Global Health. Centers for Disease Control and Prevention. Malaria surveillance--United States, 2009. MMWR Surveill Summ 2011 Apr;60(3):1-15.

(5) Mali S, Steele S, Slutsker L, Arguin P. Malaria surveillance--United States, 2008. MMWR 2010;59(7):1-15.

(6) Centers for Disease Control and Prevention (CDC). CDC Health Information for International Travel 2012. New York: Oxford University Press; 2012.

(7) Committee to Advise on Tropical Medicine and Travel. Canadian Recommendations for the Prevention and Treatment of Malaria (in press). http://publications.gc.ca/site/eng/463465/publication.html

(8) World Health Organization. International Travel and Health. Geneva, Switzerland: World Health Organization; 2012.

(9) Bradley D, Bannister B, Health Protection Agency Advisory Committee on Malaria Prevention for UK Travellers. Guidelines for malaria prevention in travellers from the United Kingdom for 2003. Commun Dis Public Health 2003;6(3):180-199.

(10) Steffen R, deBernardis C, Banos A. Travel epidemiology--a global perspective. Int J Antimicrob Agents 2003;21(2):89-95.

(11) Leder K, Black J, O'Brien D, Greenwood Z, Kain KC, Schwartz E, et al. Malaria in travelers: a review of the GeoSentinel surveillance network. Clin Infect Dis 2004 Oct;39(8):1104-1112.

(12) Chatterjee S. Compliance of malaria chemoprophylaxis among travelers to India. J Travel Med 1999 Mar;6(1):7-11.

(13) Laver SM, Wetzels J, Behrens RH. Knowledge of malaria, risk perception, and compliance with prophylaxis and personal and environmental preventive measures in travelers exiting Zimbabwe from Harare and Victoria Falls International airport. J Travel Med 2001 Nov-Dec;8(6):298-303.

(14) Banerjee D, Stanley PJ. Malaria chemoprophylaxis in UK general practitioners traveling to South Asia. J Travel Med 2001 Jul-Aug;8(4):173-175.

(15) Lobel HO, Baker MA, Gras FA, Stennies GM, Meerburg P, Hiemstra E, et al. Use of malaria prevention measures by North American and European travelers to East Africa. J Travel Med 2001 Jul-Aug;8(4):167-172. 
(16) Leonard L, VanLandingham M. Adherence to travel health guidelines: the experience of Nigerian immigrants in Houston, Texas. J Immigr Health 2001 Jan;3(1):31-45.

(17) Morgan M, Figueroa-Munoz Jl. Barriers to uptake and adherence with malaria prophylaxis by the African community in London, England: focus group study. Ethn Health 2005 Nov;10(4):355-372.

(18) Alon D, Shitrit P, Chowers M. Risk behaviors and spectrum of diseases among elderly travelers: a comparison of younger and older adults. J Travel Med 2010 Jul-Aug;17(4):250-255.

(19) Toovey S, Moerman F, van Gompel A. Special infectious disease risks of expatriates and long-term travelers in tropical countries. Part I: malaria. J Travel Med 2007 Jan-Feb;14(1):42-49.

(20) Baggett HC, Graham S, Kozarsky PE, Gallagher N, Blumensaadt S, Bateman J, et al. Pretravel health preparation among US residents traveling to India to VFRs: importance of ethnicity in defining VFRs. J Travel Med 2009 Mar-Apr;16(2):112-118.

(21) Piyaphanee W, Wattanagoon Y, Silachamroon U, Mansanguan C, Wichianprasat P, Walker E. Knowledge, attitudes, and practices among foreign backpackers toward malaria risk in southeast Asia. J Travel Med 2009 Mar-Apr;16(2):101-106.

(22) Abraham C, Clift S, Grabowski P. Cognitive predictors of adherence to malaria prophylaxis regimens on return from a malarious region: a prospective study. Soc Sci Med 1999;48(11):1641-54.

(23) Queyriaux B, Texier G, Ollivier L, Galoisy-Guibal L, Michel R, Meynard JB, et al. Plasmodium vivax malaria among military personnel, French Guiana, 1998-2008. Emerg Infect Dis 2011 Jul;17(7):1280-1282.

(24) Kain KC, MacPherson DW, Kelton T, Keystone JS, Mendelson J, MacLean JD. Malaria deaths in visitors to Canada and in Canadian travellers: a case series. CMAJ 2001 Mar;164(5):654-659.

(25) Landry P, lorillo D, Darioli R, Burnier M, Genton B. Do travelers really take their mefloquine malaria chemoprophylaxis? Estimation of adherence by an electronic pillbox. J Travel Med 2006 Jan-Feb;13(1):8-14.

(26) Molle I, Christensen KL, Hansen PS, Dragsted UB, Aarup M, Buhl MR. Use of medical chemoprophylaxis and antimosquito precautions in Danish malaria patients and their traveling companions. J Travel Med 2000 Sep-Oct;7(5):253-258.

(27) Ollivier L, Michel R, Carlotti MP, Mahe P, Romand O, Todesco A, et al. Chemoprophylaxis compliance in a French battalion after returning from malaria-endemic area. J Travel Med 2008 Sep-Oct;15(5):355-357.

(28) Lindsay SW, Jawara M, Paine K, Pinder M, Walraven GEL, Emerson PM. Changes in house design reduce exposure to malaria mosquitoes. Trop Med Int Health 2003;8(6):512-517.

(29) Lindsay SW, Emerson PM, Charlwood JD. Reducing malaria by mosquito-proofing houses. Trends Parisitol 2002;18(11):510-514.

(30) Njie M, Dilger E, Lindsay S, Kirby M. Importance of eaves to house entry by anopheline, but not culicine, mosquitoes. J Med Entomol 2009;46(3):505-10.

(31) Christophers SR. Mosquito repellents; being a report of the work of the Mosquito Repellent Inquiry, Cambridge, 1943-5. J Hyg 1947;45(2):176-231.

(32) Schoepke A, Steffen R, Gratz N. Effectiveness of personal protection measures against mosquito bites for malaria prophylaxis in travelers. J Travel Med 1998;5(4):188-192.

(33) Joy RJT. Malaria in American troops in the South and Southwest Pacific in World War II. Med Hist 1999;43(02):192-207.

(34) Maia M, Moore S. Plant-based insect repellents: a review of their efficacy, development and testing. Malar J 2011;10:S11. 
(35) Moore SJ, Debboun M. History of insect repellents. In: Debboun M, Francis S, Strickman DA, editors. Insect repellents: principles, methods and uses. 1st ed.: CRC Press; 2006. p. 3-29.

(36) Lengeler C. Insecticide-treated bed nets and curtains for preventing malaria. Cochrane Database Syst Rev 2004;2(CD000363).

(37) Schreck CE, Posey K, Smith D. Durability of permethrin as a potential clothing treatment to protect against blood-feeding arthropods. J Econ Entomol 1978;71(3):397-400.

(38) Schreck CE, Haile DG, Kline DL. The effectiveness of permethrin and deet, alone or in combination, for protection against Aedes taeniorhynchus. Am J Trop Med Hyg 1984;33(4):725-730.

(39) Vaughn MF, Meshnick SR. Pilot study assessing the effectiveness of long-lasting permethrin-impregnated clothing for the prevention of tick bites. Vector Borne Zoonotic Dis 2011;11(7):869-875.

(40) Soto J, Medina F, Dember N, Berman J. Efficacy of permethrin-impregnated uniforms in the prevention of malaria and leishmaniasis in Colombian soldiers. Clin Infect Dis 1995 Sep;21(3):599-602.

(41) Shanks GD, Kremsner PG, Sukwa TY, Van Der Berg JD, Shapiro TA, Scott TR, et al. Atovaquone and proguanil hydrochloride for prophylaxis of malaria. J Travel Med 1999;6(Suppl 1):S21-S27.

(42) Sanchez J, DeFraites R, Sharp T, Hanson R. Mefloquine or doxycycline prophylaxis in US troops in Somalia. Lancet 1993;341(8851):1021-12.

(43) Koren G, Matsui D, Bailey B. DEET-based insect repellents: safety implications for children and pregnant and lactating women. CMAJ 2003;169(3):209-12.

(44) Ohrt C, Richie T, Widjaja H, Shanks G, Fitriadi J, Fryauff D, et al. Mefloquine compared with doxycycline for the prophylaxis of malaria in Indonesian soldiers. A randomized, double-blind, placebo-controlled trial. Ann Intern Med 1997;126(12):963-72.

(45) Weiss W, Oloo A, Johnson A, Koech D, Hoffman S. Daily primaquine is effective for prophylaxis against falciparum malaria in Kenya: comparison with mefloquine, doxycycline, and chloroquine plus proguanil. J Infect Dis 1995;171(6):1569-75.

(46) Sukwa T, Mulenga M, Chisdaka N, Roskell N, Scott T. A randomized, double-blind, placebo-controlled field trial to determine the efficacy and safety of Malarone (atovaquone/proguanil) for the prophylaxis of malaria in Zambia. Am J Trop Med Hyg 1999;60(4):521-5.

(47) Shanks G, Gordon D, Klotz F, Aleman G, Oloo A, Sadie D, et al. Efficacy and safety of atovaquone/proguanil as suppressive prophylaxis for Plasmodium falciparum malaria. Clin Infect Dis 1998;27(3):494-9.

(48) Centers for Disease Control and Prevention (CDC). CDC Health Information for International Travel 2014. New York: Oxford University Press; 2013.

(49) Wongsrichanalai C, Sirichaisinthop J, Karwacki JJ, Congpuong K, Miller RS, Pang L, et al. Drug resistant malaria on the Thai-Myanmar and Thai-Cambodian borders. Southeast Asian J Trop Med Public Health 2001 Mar;32(1):41-49.

(50) Wongsrichanalai C, Pickard AL, Wernsdorfer WH, Meshnick SR. Epidemiology of drug-resistant malaria. Lancet Infect Dis 2002 Apr;2(4):209-218.

(51) Newman R, Parise M, Barber A, Steketee R. Malaria-related deaths among U.S. travelers, 1963-2001. Ann Intern Med 2004;141(7):547-55.

(52) Lell B, Luckner D, Ndjave M, Scott T, Kremsner P. Randomised placebo-controlled study of atovaquone plus proguanil for malaria prophylaxis in children. Lancet 1998;351(9104):709-13. 
(53) Camus D, Djossou F, Schilthuis HJ, Hogh B, Dutoit E, Malvy D, et al. Atovaquone-proguanil versus chloroquine-proguanil for malaria prophylaxis in nonimmune pediatric travelers: results of an international, randomized, open-label study. Clin Infect Dis 2004 Jun;38(12):1716-1723.

(54) Krudsood S, Patel SN, Tangpukdee N, Thanachartwet W, Leowattana W, Pornpininworakij K, et al. Efficacy of atovaquone-proguanil for treatment of acute multidrug-resistant Plasmodium falciparum malaria in Thailand. Am J Trop Med Hyg 2007 Apr;76(4):655-658.

(55) Humar A, Sharma S, Zoutman D, Kain KC. Fatal falciparum malaria in Canadian travellers. CMAJ 1997 April;156(8):1165-1167.

(56) Centers for Disease Control and Prevention (CDC). Malaria deaths following inappropriate malaria chemoprophylaxis--United States, 2001. MMWR Morb Mortal Wkly Rep 2001 Jul;50(28):597-599.

(57) Pistone T, Ezzedine K, Gaudin AF, Hercberg S, Nachbaur G, Malvy D. Malaria prevention behaviour and risk awareness in French adult travellers. Travel Med Infect Dis 2010 Jan;8(1):13-21.

(58) Ropers G, Du Ry van Beest Holle M, Wichmann O, Kappelmayer L, Stuben U, Schonfeld C, et al. Determinants of malaria prophylaxis among German travelers to Kenya, Senegal, and Thailand. J Travel Med 2008 May-Jun;15(3):162-171.

(59) Held TK, Weinke T, Mansmann U, Trautmann M, Pohle HD. Malaria prophylaxis: identifying risk groups for non-compliance. Q J Med 1994 Jan;87(1):17-22.

(60) Institut de médecine sociale et préventive de l'Université de Zurich. Santé-voyages: Vaccinations et mesures antipaludiques 2010. 2010; Available at:

http://www.bag.admin.ch/themen/medizin/00682/00685/03062/index.html?lang=fr. Accessed November 18, 2010.

(61) World Health Organization. International Travel and Health, Country List. 2011; Available at: http://www.who.int/ith/en/.

(62) Deutsche Gesellschaft für Tropenmedizin und Internationale Gesundheit (DTG). Empfehlungen zur Malariavorbeugung. 2011; Available at: http://www.dtg.org/uploads/media/Malaria_2011.pdf. Accessed June 12, 2011.

(63) Office fédéral de la santé publique, Confédération suisse, Division maladies transmissibles. Paludisme (malaria) - mise à jour 2010. OFSP 2010;19:506-8.

(64) Smittskyddsinstitutet. Rekommendationer för malariaprofylax 2010. 2010; Available at: http://www.folkhalsomyndigheten.se/publicerat-material/publikationer/?topic=smittskydd-och-sjukdomar. Accessed November 24, 2010.

(65) International Association for Medical Assistance to Travellers 2011. World Malaria Risk Chart. 2011; Available at: http://www.iamat.org/disease_details.cfm?id=140.

(66) Haut Conseil de la santé publique. Recommandations sanitaires pour les voyageurs 2011 (à l'attention des professionnels de santé). 2011; Available at: http://opac.invs.sante.fr/doc_num.php?explnum_id=7068. Accessed June 1, 2011.

(67) Statistics Canada. International Travel Survey: Canadian Residents 2012 (Custom Extract). 


\section{Appendix}

\section{Appendix: Malaria risk and recommended chemoprophylaxis in top 25 malaria-endemic travel destinations visited by Canadians in 2012 (6, 60-67)}

\begin{tabular}{|c|c|c|c|c|c|}
\hline \multicolumn{2}{|r|}{ Country } & Malaria transmission areas ${ }^{(2-4)}$ & $\begin{array}{l}\text { Chemoprophylaxis } \\
\text { recommended by }\end{array}$ & Season ${ }^{(3 ; 4)}$ & $\begin{array}{c}\text { Plasmodium } \\
\text { falciparum }^{(2-4)}\end{array}$ \\
\hline \multirow[t]{3}{*}{1} & \multirow[t]{3}{*}{ Mexico } & $\begin{array}{l}\text { Minimal or no malaria transmission in major } \\
\text { resort areas on the coasts, including the city } \\
\text { of Acapulco or along the Mayan Riviera, } \\
\text { including the cities of Cancún, Cozumel, and } \\
\text { Playa del Carmen. None along the border with } \\
\text { the United States. } \\
\text { Little malaria transmission in the states of } \\
\text { Jalisco, Quintana Roo, Sonora and Tabasco. }\end{array}$ & $\begin{array}{l}\text { None. } \\
\text { Use PPM. }\end{array}$ & \multirow[t]{3}{*}{ Year-round } & \multirow[t]{3}{*}{0} \\
\hline & & $\begin{array}{l}\text { Moderate risk in parts of the states of Chiapas } \\
\text { and Oaxaca. }\end{array}$ & Chloroquine. & & \\
\hline & & $\begin{array}{l}\text { Low risk in rural areas of the states of Nayarit, } \\
\text { Sinaloa, Chihuahua, and Durango. }\end{array}$ & $\begin{array}{l}\text { Chloroquine for stays }>1 \\
\text { week; chloroquine or PPM } \\
\text { alone for stays of } \leq 1 \text { week. }\end{array}$ & & \\
\hline \multirow[t]{3}{*}{2} & \multirow[t]{3}{*}{$\begin{array}{l}\text { Dominican } \\
\text { Republic }\end{array}$} & $\begin{array}{l}\text { Little to no malaria transmission in the resort } \\
\text { areas of Romana and Samaná and the cities } \\
\text { of Santo Domingo, Santiago, and Puerto } \\
\text { Plata. }\end{array}$ & None; use PPM. & \multirow{3}{*}{ Year-round } & \multirow{3}{*}{100} \\
\hline & & $\begin{array}{l}\text { Some transmission has previously occurred in } \\
\text { La Altagracia province, including resort areas } \\
\text { such as Punta Cana. }\end{array}$ & $\begin{array}{l}\text { In the absence of any } \\
\text { further outbreaks in La } \\
\text { Altagracia, PPM alone for } \\
\text { resorts in that province. } \\
\text { Seek medical attention if a } \\
\text { fever develops. }\end{array}$ & & \\
\hline & & $\begin{array}{l}\text { Rural areas, with the highest risk in the } \\
\text { provinces of Dajabón, Elias Piña, and San } \\
\text { Juan bordering Haiti. }\end{array}$ & Chloroquine. & & \\
\hline \multirow[t]{4}{*}{3} & \multirow[t]{4}{*}{ China } & $\begin{array}{l}\text { No malaria transmission in urban areas or } \\
\text { northern China. }\end{array}$ & None. & $\mathrm{n} / \mathrm{a}$ & $\mathrm{n} / \mathrm{a}$ \\
\hline & & $\begin{array}{l}\text { Limited transmission of } P \text {. vivax malaria } \\
\text { occurs in the southern provinces and some } \\
\text { central provinces, including Anhui, Ghuizhou, } \\
\text { Henan, Hubei, and Jiangsu. } \\
\text { The risk of contracting malaria in central } \\
\text { China is small. }\end{array}$ & $\begin{array}{l}\text { For travellers visiting major } \\
\text { cities and making daytime } \\
\text { excursions into the } \\
\text { countryside or on Yangtze } \\
\text { river cruises: none; use } \\
\text { PPM. } \\
\text { For those travelling } \\
\text { extensively in or through } \\
\text { rural southern China: } \\
\text { chloroquine. }\end{array}$ & \multirow[t]{3}{*}{ Year-round } & \multirow[t]{3}{*}{9} \\
\hline & & $\begin{array}{l}\text { Transmission of } P \text {.falciparum malaria occurs } \\
\text { in the province of Yunnan and, to a lesser } \\
\text { extent, in the province of Hainan. } P \text {. } \\
\text { falciparum resistance to chloroquine and } \\
\text { sulfadoxine-pyrimethamine reported. }\end{array}$ & ATQ-PG, DOXY or MFQ. & & \\
\hline & & $\begin{array}{l}P . \text { falciparum resistance to mefloquine } \\
\text { reported in the province of Yunnan in the } \\
\text { areas bordering Burma (Myanmar). }\end{array}$ & ATQ-PG or DOXY. & & \\
\hline \multirow[t]{2}{*}{4} & \multirow[t]{2}{*}{ India } & $\begin{array}{l}\text { No malaria transmission at elevations }>2000 \\
m \text { in parts of the states of Himachal Pradesh, } \\
\text { Jammu and Kashmir, and Sikkim. }\end{array}$ & None. & $\mathrm{n} / \mathrm{a}$ & $\mathrm{n} / \mathrm{a}$ \\
\hline & & $\begin{array}{l}\text { All other areas - including most urban areas } \\
\text { such as Bombay (Mumbai) and Delhi. } \\
\text { Risk is lower in most of the southernmost } \\
\text { regions of India. } \\
\text { Risk is low in central urban areas of Agra and } \\
\text { Bangalore. }\end{array}$ & $\begin{array}{l}\text { PPM alone can be } \\
\text { considered for stays of }<1\end{array}$ & Year-round & $>40$ \\
\hline
\end{tabular}




\begin{tabular}{|c|c|c|c|c|c|}
\hline & & & $\begin{array}{l}\text { week in central urban areas } \\
\text { of Delhi, Agra and } \\
\text { Bangalore. }\end{array}$ & & \\
\hline \multirow[t]{2}{*}{5} & \multirow[t]{2}{*}{ Costa Rica } & $\begin{array}{l}\text { Little to no risk of malaria transmission in most } \\
\text { of the country, with exception noted below. } \\
\text { No malaria transmission in the city of Limón } \\
\text { (Puerto Limón). }\end{array}$ & None; use PPM. & \multirow[t]{2}{*}{ Year-round } & \multirow[t]{2}{*}{$\begin{array}{l}\text { Predominantly } \\
\quad P \text { vivax }\end{array}$} \\
\hline & & $\begin{array}{l}\text { Limón province (except the city of Limón), } \\
\text { mostly in the canton of Matina. }\end{array}$ & Chloroquine. & & \\
\hline \multirow[t]{2}{*}{6} & \multirow[t]{2}{*}{ Thailand } & $\begin{array}{l}\text { No malaria transmission in cities, including } \\
\text { Bangkok, Chiang Mai, Chiang Rai, Pattaya, } \\
\text { Koh Samui, Phang Nga, Town of Phuket and } \\
\text { Koh Phangan, or in major tourist resorts. }\end{array}$ & None. & $\mathrm{n} / \mathrm{a}$ & $\mathrm{n} / \mathrm{a}$ \\
\hline & & $\begin{array}{l}\text { Rural forested areas near the borders with } \\
\text { Cambodia, Burma (Myanmar) and Laos. } \\
\text { Rural forested areas in districts of Phang Nga } \\
\text { and Phuket. Some islands have malaria risk. } \\
\text { Mefloquine resistance reported. }\end{array}$ & ATQ-PG or DOXY. & Year-round & $50-75$ \\
\hline \multirow[t]{2}{*}{7} & \multirow[t]{2}{*}{ Philippines } & $\begin{array}{l}\text { Little to no malaria transmission in urban } \\
\text { areas or on islands not listed below. }\end{array}$ & None; use PPM. & \multirow[b]{2}{*}{ Year-round } & \multirow[b]{2}{*}{$70-80$} \\
\hline & & $\begin{array}{l}\text { Rural areas at elevations }<600 \mathrm{~m} \text { on islands } \\
\text { of Basilu, Luzon, Mindanao, Mindoro, } \\
\text { Palawan, Sulu (Jolo) and Tawi-Tawi. }\end{array}$ & ATQ-PG, DOXY or MFQ. & & \\
\hline \multirow[t]{2}{*}{8} & \multirow[t]{2}{*}{$\begin{array}{l}\text { South } \\
\text { Africa }\end{array}$} & $\begin{array}{l}\text { No malaria transmission in most of the } \\
\text { country including the Garden Route and major } \\
\text { cities. }\end{array}$ & None. & $\mathrm{n} / \mathrm{a}$ & $\mathrm{n} / \mathrm{a}$ \\
\hline & & $\begin{array}{l}\text { Low-altitude areas in the provinces of } \\
\text { Mpumalanga (including the Kruger National } \\
\text { Park), Limpopo (formerly Northern), and } \\
\text { north-eastern Kwa Zulu-Natal as far south as } \\
\text { the Tugela River. }\end{array}$ & ATQ-PG, DOXY or MFQ. & $\begin{array}{l}\text { Year-round } \\
\text { (risk is } \\
\text { highest } \\
\text { from Oct- } \\
\text { May) }\end{array}$ & 90 \\
\hline \multirow[t]{2}{*}{9} & \multirow[t]{2}{*}{ Peru } & $\begin{array}{l}\text { No malaria risk at elevations }>2000 \mathrm{~m} \text {, } \\
\text { including the highland tourist areas (Machu } \\
\text { Picchu, Lake Titicaca, and the cities of } \\
\text { Arequipa, Cuzco, Puno) or in the cities of } \\
\text { Limaand south of Lima including Moquegua, } \\
\text { Nazca, and Tacna. }\end{array}$ & None. & $\mathrm{n} / \mathrm{a}$ & $\mathrm{n} / \mathrm{a}$ \\
\hline & & $\begin{array}{l}\text { All areas }<2000 \mathrm{~m} \text { (except cities listed } \\
\text { above). This includes the cities of Puerto } \\
\text { Maldonado and lquitos. Most P.falciparum } \\
\text { cases occur in the region of Loreto. }\end{array}$ & ATQ-PG, DOXY or MFQ. & Year-round & 15 \\
\hline \multirow[t]{2}{*}{10} & \multirow[t]{2}{*}{ Turkey } & $\begin{array}{l}\text { No malaria transmission in western and } \\
\text { northeastern parts of the country, including } \\
\text { the common tourist destinations of the cities } \\
\text { of Izmir and Istanbul and the Cappadocia } \\
\text { region. }\end{array}$ & None. & $\mathrm{n} / \mathrm{a}$ & $\mathrm{n} / \mathrm{a}$ \\
\hline & & $\begin{array}{l}\text { Limited malaria transmission in the } \\
\text { southeastern part of the country. }\end{array}$ & $\begin{array}{l}\text { Chloroquine for stays }>2 \\
\text { weeks; chloroquine or PPM } \\
\text { alone for stays of } \leq 2 \text { weeks. }\end{array}$ & May-Oct & Sporadically \\
\hline \multirow[t]{3}{*}{11} & \multirow[t]{3}{*}{ Argentina } & $\begin{array}{l}\text { No malaria transmission in urban areas, } \\
\text { Iguassu Falls, or provinces not listed below. }\end{array}$ & None. & $\mathrm{n} / \mathrm{a}$ & $\mathrm{n} / \mathrm{a}$ \\
\hline & & $\begin{array}{l}\text { Rare in Misiones province along the border } \\
\text { with Paraguay. }\end{array}$ & None; use PPM. & \multirow[b]{2}{*}{ Oct-May } & \multirow[b]{2}{*}{0} \\
\hline & & $\begin{array}{l}\text { Rural areas of northern Jujuy and Salta } \\
\text { Province (along Bolivian border). }\end{array}$ & $\begin{array}{l}\text { Chloroquine for stays }>2 \\
\text { weeks; chloroquine or PPM } \\
\text { alone for stays of } \square 2 \\
\text { weeks. }\end{array}$ & & \\
\hline \multirow[t]{2}{*}{12} & \multirow[t]{2}{*}{ Brazil } & $\begin{array}{l}\text { Little to no malaria transmission at Iguazu } \\
\text { Falls; in the Pantanal region; in the cities of } \\
\text { Brasília, Recife, Rio de Janeiro, São Paulo, } \\
\text { and Salvador; or in other areas not listed } \\
\text { below. }\end{array}$ & None; use PPM. & \multirow[t]{2}{*}{ Year-round } & \multirow[t]{2}{*}{15} \\
\hline & & $\begin{array}{l}\text { Areas at elevations }<900 \mathrm{~m} \text { in most forested } \\
\text { areas of the states of Acre, Amapá, } \\
\text { Amazonas, Rondônia, Roraima and Tocantins }\end{array}$ & ATQ-PG, DOXY or MFQ. & & \\
\hline
\end{tabular}




\begin{tabular}{|c|c|c|c|c|c|}
\hline & & $\begin{array}{l}\text { (western part) and parts of states of } \\
\text { Maranhāo (western part), Mato Grosso } \\
\text { (northern part), Pará (except Belém City) and } \\
\text { Tocantins (western part). Transmission also } \\
\text { occurs in some peripheral urban areas of - } \\
\text { Boa Vista, Cruziero do Sul, Macapá, Manaus, } \\
\text { Maraba, Pôrto Velho, Rio Branco, and } \\
\text { Santarém. }\end{array}$ & & & \\
\hline \multirow[t]{3}{*}{13} & \multirow[t]{3}{*}{ Belize } & $\begin{array}{l}\text { No malaria transmission in Belize City and } \\
\text { islands frequented by tourists. }\end{array}$ & None. & $\mathrm{n} / \mathrm{a}$ & $\mathrm{n} / \mathrm{a}$ \\
\hline & & $\begin{array}{l}\text { Low risk in Belize, Corozal, and Orange Walk } \\
\text { Districts. }\end{array}$ & None; use PPM. & \multirow{2}{*}{ Year-round } & \multirow{2}{*}{$0-5$} \\
\hline & & $\begin{array}{l}\text { Moderate risk in Cayo, Stann Creek, and } \\
\text { Toledo Districts. }\end{array}$ & Chloroquine. & & \\
\hline \multirow[t]{2}{*}{14} & \multirow[t]{2}{*}{ Ecuador } & $\begin{array}{l}\text { No malaria transmission at elevations } \\
>1500 \mathrm{~m} \text {, including Cuenca, Quito, and other } \\
\text { cities and villages in the Andean highlands; in } \\
\text { the city of Guayaquil or on the Galápagos } \\
\text { Islands. }\end{array}$ & None. & $\mathrm{n} / \mathrm{a}$ & $\mathrm{n} / \mathrm{a}$ \\
\hline & & $\begin{array}{l}\text { All other areas at elevations }<1500 \mathrm{~m} . \\
\text { Higher risk along the coast, in the north. }\end{array}$ & ATQ-PG, DOXY or MFQ. & Year-round & 10 \\
\hline \multirow[t]{2}{*}{15} & \multirow[t]{2}{*}{ Colombia } & $\begin{array}{l}\text { No malaria transmission in urban areas, } \\
\text { including Bogotá and vicinity and Cartagena; } \\
\text { at elevations }>1600 \mathrm{~m} \text {; or on the islands of } \\
\text { San Andrés and Providencia in the Caribbean } \\
\text { Sea. }\end{array}$ & None. & $\mathrm{n} / \mathrm{a}$ & $\mathrm{n} / \mathrm{a}$ \\
\hline & & Rural or jungle areas at elevations $<1600 \mathrm{~m}$. & ATQ-PG, DOXY or MFQ. & Year-round & $35-40$ \\
\hline \multirow[t]{2}{*}{16} & \multirow[t]{2}{*}{ Guatemala } & $\begin{array}{l}\text { No malaria transmission in urban areas or } \\
\text { areas at elevations }>1500 \mathrm{~m} \text { none in } \\
\text { Guatemala City, Antigua, and Lake Atitlán. }\end{array}$ & None. & $\mathrm{n} / \mathrm{a}$ & $\mathrm{n} / \mathrm{a}$ \\
\hline & & Rural areas at elevations $<1500 \mathrm{~m}$. & Chloroquine. & Year-round & 3 \\
\hline \multirow[t]{2}{*}{17} & \multirow[t]{2}{*}{ Honduras } & $\begin{array}{l}\text { No malaria transmission - in the cities of } \\
\text { Tegucigalpa and San Pedro Sula. } \\
\text { Risk is low in higher mountainous areas in the } \\
\text { west where PPM can be considered. }\end{array}$ & None. & $\mathrm{n} / \mathrm{a}$ & $\mathrm{n} / \mathrm{a}$ \\
\hline & & $\begin{array}{l}\text { Risk is high in departments of Gracias a Dios } \\
\text { and Islas de la Bahia (Bay Islands), and } \\
\text { moderate in Atlantida, Colon, Olancho, and } \\
\text { Yoro. }\end{array}$ & Chloroquine. & Year-round & 7 \\
\hline \multirow[t]{3}{*}{18} & \multirow[t]{3}{*}{ Vietnam } & $\begin{array}{l}\text { None in urban areas, Red River Delta and } \\
\text { coastal plain of central Vietnam. } \\
\text { Rare cases in Mekong Delta. } \\
\text { The common coastal itinerary between Ho Chi } \\
\text { Minh City and Hanoi with overnights mainly in } \\
\text { urban areas does not typically require } \\
\text { chemoprophylaxis. }\end{array}$ & Use PPM. & \multirow{3}{*}{ Year-round } & \multirow{3}{*}{$50-90$} \\
\hline & & $\begin{array}{l}\text { Rural areas, excluding those listed above. } \\
\text { Risk in the town of Sapa in the hills to the } \\
\text { northwest of Hanoi is lower; PPM can be } \\
\text { considered for stays }<1 \text { week, particularly in } \\
\text { the winter months. }\end{array}$ & ATQ-PG, DOXY or MFQ. & & \\
\hline & & $\begin{array}{l}\text { Mefloquine resistance reported in the } \\
\text { southern part of the country in the provinces } \\
\text { of Dac Lac, Gia Lai, Khanh Hoa (western } \\
\text { part), Kon Tum, Lam Dong, Ninh Thuan } \\
\text { (western part), Song Be, and Tay Ninh. }\end{array}$ & ATQ-PG or DOXY. & & \\
\hline \multirow[t]{2}{*}{19} & \multirow[t]{2}{*}{ Cambodia } & $\begin{array}{l}\text { No malaria transmission in the city of Phnom } \\
\text { Penh and the area around Lake Tonlé Sap } \\
\text { (Siem Reap). Negligible transmission in the } \\
\text { tourist area of Angkor Wat and Siem Reap. }\end{array}$ & None; use PPM. & \multirow[t]{2}{*}{ Year-round } & \multirow[t]{2}{*}{86} \\
\hline & & $\begin{array}{l}\text { Mefloquine resistance is reported in the } \\
\text { western provinces of Banteay Meanchey, }\end{array}$ & $\begin{array}{l}\text { Doxycycline or } \\
\text { atovaquone-proguanil. }\end{array}$ & & \\
\hline
\end{tabular}




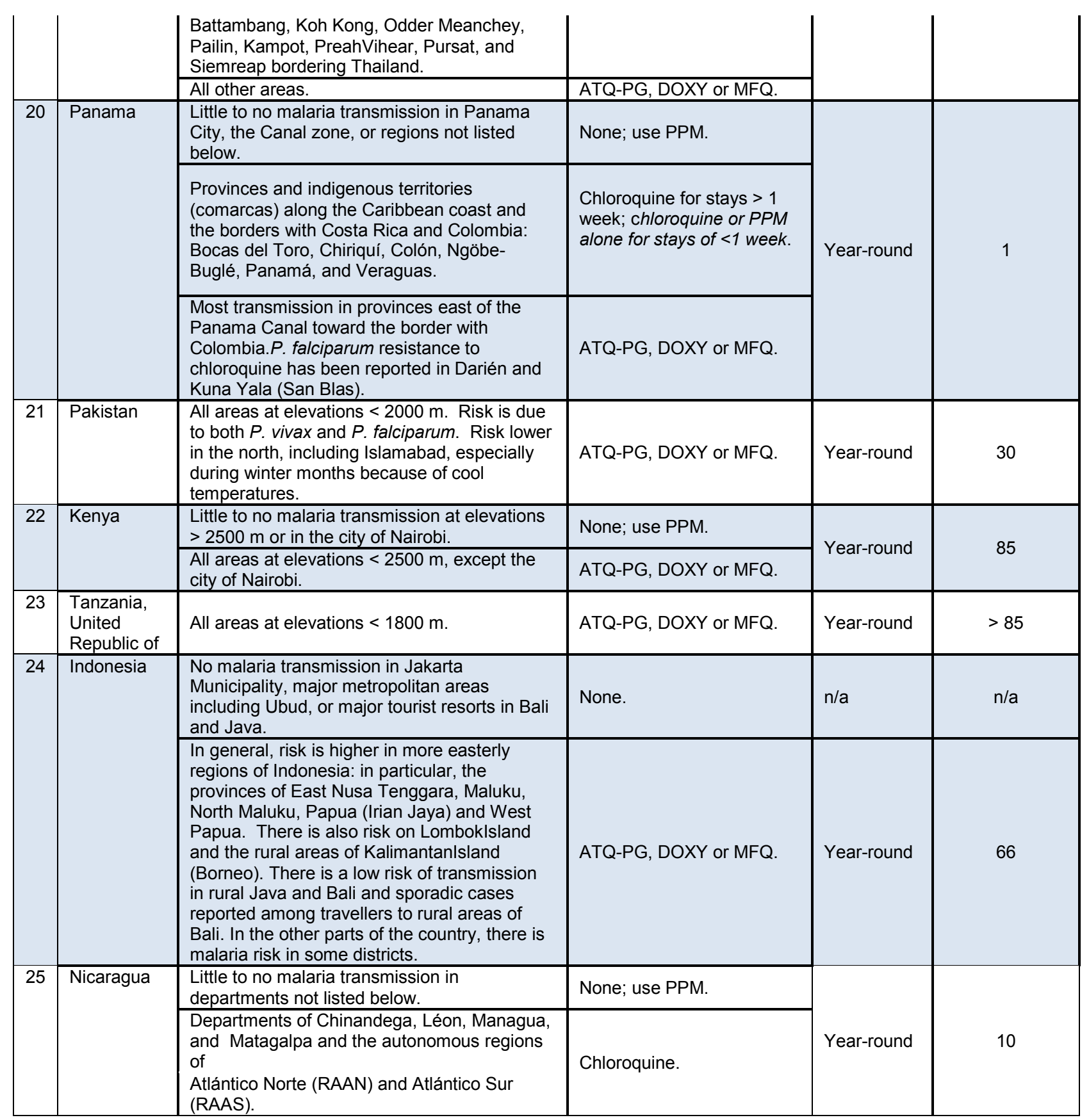

* Chemoprophylaxis is recommended only in the risk areas identified during the transmission season identified. Chemoprophylaxis should always be used in conjunction with PPM.

ATQ-PG, atovaquone-proguanil; DOXY, doxycycline; MFQ, melfloquine 